\title{
Pequi Oil Microencapsulation by Complex Coacervation using Gelatin-Cashew Gum
}

\author{
Marília Alves do Nascimento ${ }^{a}$, Luana Carvalho da Silva ${ }^{a}$, Luana Guabiraba \\ Mendes $^{a}$, Roselayne Ferro Furtado ${ }^{b^{*}}$, José Maria Correia da Costa ${ }^{\mathrm{c}}$, Atanu \\ Biswas $^{d}$, Huai N. Cheng $^{\mathrm{e}}$, and Carlucio Roberto Alves ${ }^{\mathrm{a}}$ \\ ${ }^{\text {a }}$ State University of Ceará, Science and Technology Center - Zip-code: 60.714-903, Fortaleza - CE, Brazil \\ b Embrapa Agroindústria Tropical - Food Packaging Laboratory - Zip-code: 60.511-110, Fortaleza - CE, Brazil \\ ${ }^{\mathrm{c}}$ Department of Food Technology - Federal University of Ceará, Agrarian Sciences Center - Zip-code: \\ 60356-001, Fortaleza - CE, Brazil \\ ${ }^{\mathrm{d}}$ USDA Agricultural Research Service, National Center for Agricultural Utilization Research, 1815 North \\ University Street Peoria, Illinois 61604, USA \\ e USDA Agricultural Research Service, Southern Regional Research Center, 1100 Robert E. Lee Blvd., New \\ Orleans, LA 70124, USA \\ * Corresponding author \\ roselayne.furtado@embrapa.br \\ TEL: +558533917362
}

Received: 23 January 2019; Published online: 18 January 2020

\begin{abstract}
New functional foods and beverages can be developed using bioactive compounds present in pequi oil. Complex coacervation is an encapsulation method used for preserving bioactive molecules, especially those that are hydrophobic or sensitive to high temperatures. The objective of this work was to produce and characterize pequi oil microparticles using cashew gum/gelatin matrix (CG/GE) through complex coacervation. Gum Arabic (GA) was also studied in comparison with CG. The coacervation process was performed without pequi oil to determine the ideal proportions of the matrix components, followed by the embedding of the oil in the microparticles for evaluation. Satisfactory microparticles were produced at $\mathrm{pH} 4.5$ in the weight ratios of $\mathrm{CG} / \mathrm{GE}=2: 1$ and $\mathrm{GA} / \mathrm{GE}=1: 3$. Pequi oil release was greater in acidic $\mathrm{pH}$, especially at $\mathrm{pH} 2$ for the $\mathrm{CG} / \mathrm{GE}$ matrix. The encapsulation efficiency for $\mathrm{CG} / \mathrm{GE}$ and $\mathrm{GA} / \mathrm{GE}$ was $72.53 \%( \pm 4.80)$ and $82.77 \%( \pm 6.09)$, respectively. The results showed that the $\mathrm{CG} / \mathrm{GE}$ combination seemed very promising as an encapsulation matrix, especially for food applications involving $\mathrm{pH}$ values higher than 3 .
\end{abstract}

Keywords: Anacardium occidentale; Coacervate; Encapsulation; Gelatin; Caryocar coriaceum; Polysaccharides

\section{Introduction}

Microencapsulation is often used in powder technology to describe the process of forming an amorphous polymeric coating around a core to control mass transfer and provide protection in the dry state from interactions with its envir- onment, thereby minimizing changes in colour, aroma and flavour and enabling controlled release (Gouin, 2004).

The particles derived from encapsulation methods often display different physical shapes and structures that influence the release profile and storage stability of the core material (Aguilera, 
2005; Re, 2006). In the present study, microencapsulation was achieved through the complex coacervation method, which entails the preparation of a mixture of polyelectrolytes of opposite charges in an aqueous solution, resulting in separate layers; the dense layer is rich in polymers (coacervate) and the dilute phase is depleted in polymers (Black et al., 2014). This method is also recommended for the microencapsulation of hydrophobic materials and/or substances sensitive to high temperatures (Alvim \& Ferreira Grosso, 2010).

Pequi tree oil is a seed oil with a peculiar odour and aroma that is distinct and noticeable. The consumption of this oil has attracted attention due to its potential health benefits. It is rich in oleic acid (Lopes et al., 2008) and widely used in foods because of its high content of vitamins (de Paula-Ju, H. Rocha, Donatti, Fadel-Picheth \& Weffort-Santos, 2006) and carotenoids (Azevedo-Meleiro \& Rodriguez-Amaya, 2004). The presence of these compounds provides skin protection by preventing free radical formation and, therefore, slowing down the aging process (Pianovski et al., 2008). Other benefits associated with the use of this oil include treatment for gastric ulcers (Quirino et al., 2009), anti-inflammatory property, and cutaneous wound-healing support (Batista et al., 2010). In view of its beneficial effects, it is highly desirable to preserve bioactive compounds in pequi oil through microencapsulation in order to develop functional food and drinks for the market.

Gums are among the biopolymers most commonly used as wall materials in microencapsulation methods (Jafari, Mahdavi-Khazaei \& Hemmati-Kakhki, 2016; Khoshakhlagh, Koocheki, Mohebbi \& Allafchian, 2017; Revuelta, Chacon Villalba, Navarro, Guida \& Castro, 2016). Gum Arabic is widely used, despite its cost and occasional supply problems related to climatic, economic and political problems in the African region that produces it (Andrade, Carvalho \& Takeiti, 2013). Complex coacervation with gum Arabic and gelatin has been extensively investigated (Anvari \& Chung, 2016; Habibi, Keramat, Hojjatoleslamy \& Tamjidi, 2017; Lv, Yang, Li, Zhang \& Abbas, 2014); however, studies involving cashew gum-gelatin using this method are recent and relatively sparse in the literature (Comunian et al., 2016; de Souza et al., 2018; Gomez-Estaca, Comunian, Montero, Ferro-Furtado \& FavaroTrindade, 2016). Cashew gum is considered an alternative to gum Arabic, although it is not yet a commercial product (Rodrigues, 2004). Cashew gum is an anionic polysaccharide and has low viscosity in water. The negative charge on cashew gum in aqueous solution makes it possible to interact with positively charged polymers. Earlier studies in this laboratory have demonstrated cashew gum as an efficient encapsulating matrix (da Silva et al., 2018; de Oliveira, Paula \& de Paula, 2014; Gomez-Estaca et al., 2016; Rodrigues \& Grosso, 2008). In this work, pequi oil microparticles were produced using cashew gum/gelatin matrix through complex coacervation. Moreover, the particles were characterized by microscopy, encapsulation efficiency (superficial and total oil), yield and oil release, and particle size.

\section{Materials and Methods}

\subsection{Materials}

Cashew gum (CG) was collected from Anacardium occidentale L. plants from Embrapa Tropical Agroindustry Experimental Field in Ceará - Brazil (coordinates: 4²1'26.62" S and $\left.38^{\circ} 29^{\prime} 50.78^{\prime \prime} \mathrm{W}\right)$. Gum Arabic (GA) was purchased from JB Química Indústria e Comercio Ltda and the gelatin (GE) $225 \mathrm{H}$ type B was provided by Rousselot ${ }^{\circledR}$. The pequi oil ( $\mathrm{Ca}$ ryocar coriaceum Wittm.) was purchased from a local provider in Ceará, Brazil (coordinates: $07^{\circ} 18^{\prime} 19^{\prime \prime} \mathrm{S}$ and $39^{\circ} 18^{\prime} 08^{\prime \prime} \mathrm{W}$ ). All reagents used were analytical grade.

\subsection{Cashew Gum Isolation}

The isolation of cashew tree polysaccharide exudate was carried out according to Torquato et al. (2004), with some modifications. A 500 g exudate sample was ground by a knife mill and solubilized in water in the proportion of 300:1 (g/L). After solubilization, the sample was filtered, centrifuged at $15,303 \mathrm{x}$ g for $10 \mathrm{~min}$ at $25^{\circ} \mathrm{C}$ and precipitated in 1:3 ethanol $(\mathrm{v} / \mathrm{v})$ for 24 
$\mathrm{h}$ at $10^{\circ} \mathrm{C}$. The precipitate was dried in an aircirculating oven at $60^{\circ} \mathrm{C}$ for $24 \mathrm{~h}$ and was ground afterwards. The moisture of the polysaccharide isolated was $12.58 \pm 0.43 \%$.

\subsection{Microparticles without pequi oil}

Suspensions of CG 1\% (w/v), GA 1\% (w/v) and gelatin $1 \%(\mathrm{w} / \mathrm{v})$ were prepared at $\mathrm{pH} 4,4.5$ and 5 , respectively, for zeta potential analysis. From the data, the proportions of each polymer and the ideal $\mathrm{pHs}$ for the formation of the microparticles (CG/GE and GA/GE) were established in accordance with Prata and Grosso (2015).

The procedure used for the production of microparticles was as follows. The gelatin and gum Arabic solutions were prepared separately followed by homogenisation in an Ultra-Turrax homogeniser at 10,000 rpm for $3 \mathrm{~min}$ at room temperature. $100 \mathrm{~mL}$ of each suspension was homogenised in this way at room temperature. Then $400 \mathrm{~mL}$ of distilled water was added and homogenised in the Ultra-Turrax at 10,000 rpm for $3 \mathrm{~min}$ at room temperature. The $\mathrm{pH}$ was adjusted with hydrochloric acid (2M) to 4.0, 4.5 and 5.0, and the solutions were refrigerated $\left(8 \pm 2{ }^{\circ} \mathrm{C}\right)$ overnight for precipitation of the particles. Subsequently, excess water was eliminated and coacervate suspensions were obtained for the analyses.

\section{Zeta potential analysis}

Coacervate suspensions were lightly homogenised and the zeta potential was determined with a Zetasizer Nano ZS 3000 dynamic light scattering instrument (Malvern Instruments, UK), operating with a laser light at a wavelength of $633 \mathrm{~nm}$.

\section{Spectrophotometric analysis}

The coacervate formation was indirectly analyzed by the reading of suspension absorbance using a spectrophotometer (Cary 50 Conc, Varian) before and after cooling $\left(8 \pm 2{ }^{\circ} \mathrm{C}\right)$ at the wavelength of $200 \mathrm{~nm}$. Only the supernatant from each sample was used for the analysis (da Silva et al., 2018).

\section{Coacervate yield}

Coacervates were centrifuged at $15,303 \mathrm{x}$ g for 10 min at $25{ }^{\circ} \mathrm{C}$ and dried in a drying oven at 105 ${ }^{\circ} \mathrm{C}$ until constant weight was achieved. The yield was calculated through the relationship between the initial dry mass used and the final mass obtained from the formula $\mathrm{R}=100 \mathrm{~m}_{f} / \mathrm{m}_{0}$, where $\mathrm{R}$ is the percent yield, $\mathrm{mf}$ is the final dry mass and $\mathrm{m}_{0}$ the initial mass (gum mass + gelatin mass) (Huang, Sun, Xiao \& Yang, 2012).

\subsection{Microparticles with pequi oil}

Emulsions were prepared with pequi oil in gelatin dispersion at 10,000 rpm for $5 \mathrm{~min}$ at room temperature. The GA solution was then slowly added to the gelatin-stabilized emulsion to a final aqueous volume of $200 \mathrm{~mL}$, using the same procedure adopted for evaluation of the coacervation process presented before without pequi oil (Section 2.3). Five levels of pequi oil were tested: $0.5 \mathrm{~g}, 0.75 \mathrm{~g}, 1 \mathrm{~g}, 2 \mathrm{~g}$ and $2.5 \mathrm{~g}$. Coacervates were characterised for their yield, oil release property, encapsulation efficiency, and by microscopy.

\section{Characterisation by optical microscopy}

The microscopic slides were previously sterilised with $70 \%$ ethyl alcohol. A drop of the coacervate suspension and a cover slip were placed on each slide. Optical micrographs were recorded on a Zeiss optical microscope coupled with a digital image acquisition system through a CCD camera.

\section{Particle size determination}

Microparticle size was determined with the use of the Malvern 3000 Zetasizer Nano ZS laser light scattering instrument (Malvern Instruments, UK). Precipitated coacervates were suspended in isopropyl alcohol in the proportion of $0.5 \mathrm{~g}$ to $25 \mathrm{~mL}$ of alcohol. The volume moment mean diameter $\mathrm{D}_{4,3}$ was measured, which represents the diameter of a sphere with the same average volume in the sample and the Span which gives the information on the homogeneity of the 
size distribution of the particles (Hosseini et al., 2013).

\section{Yield analysis}

The yield was calculated from the formula $\mathrm{R}$ $=100 \mathrm{~m}_{f} / \mathrm{m}_{0}$ as previously described (Section 2.3.3), in which $\mathrm{R}$ is the percent yield, $\mathrm{m}_{f}$ is the final dry mass and $m_{0}$ the initial mass (gum mass + gelatin mass + oil mass) (Huang et al., 2012).

\section{Encapsulation efficiency}

The suspensions of microcapsules were previously frozen in an ultra-freezer (Liotop FV500, Liobras) and put in the freeze dryer for $72 \mathrm{~h}(\mathrm{Li}-$ otop, model K1005) for determination of surface and total oil. The moisture content (\%) was calculated on a wet-weight basis. The encapsulation efficiency (EE) was determined by Equation 1:

$$
E E(\%)=\frac{T O-S O}{T O} \times 100
$$

Where TO is the amount of the total oil and SO is the amount of the surface oil.

Determination of total oil (TO): Total oil extraction was performed according to the Bligh-Dyer method with modifications (Checci, 2003). Thus, $0.1 \mathrm{~g}$ of the freezedried microcapsules were weighed and resuspended in $10 \mathrm{~mL}$ chloroform, $20 \mathrm{~mL}$ methanol and $8 \mathrm{~mL}$ distilled water. The mixture was homogenized in a magnetic stirrer for 30 minutes; then, $10 \mathrm{~mL}$ chloroform and $10 \mathrm{~mL}$ of $1.5 \%$ sodium sulphate solution were added and stirred for another 2 min. The material was transferred to a separating funnel and allowed to stand until complete phase separation. From the organic phase, approximately $15 \mathrm{~mL}$ was collected. About $1 \mathrm{~g}$ of sodium sulphate was added to the organic phase and then filtered. A $1 \mathrm{~mL}$ portion was transferred to a $10-\mathrm{mL}$ volumetric flask, and made to volume with hexane. The amount of oil in the microparticles was calculated by using an appropriate calibration curve of free oil in hexane obtained on a spectrophotometer at $450 \mathrm{~nm}$ wavelength. Each batch of samples was measured in triplicate.

Determination of surface oil (SO): The amount of oil present on the surface of the freeze-dried microcapsules was evaluated spectrophotometrically, according to a method proposed by Higuita (2013) with modifications. About $0.1 \mathrm{~g}$ microcapsules was resuspended in $10 \mathrm{~mL}$ of hexane in a test tube and stirred on a vortex shaker for approximately $1 \mathrm{~min}$. The amount of oil in the microparticles was calculated by using an appropriate calibration curve of free oil in hexane obtained on a spectrophotometer at $450 \mathrm{~nm}$ wavelength. Each batch of samples was measured in triplicate.

\subsection{Oil release}

Pequi oil release at different $\mathrm{pH}$ ranges was evaluated using the methodology described by Comunian et al. (2016) with some modifications. After microparticle formation, the $\mathrm{pH}$ was adjusted from 2.0 to 9.0 in $100 \mathrm{~mL}$ of coacervate suspension, which was kept under agitation with a magnetic stirrer for 2 min. Hexane was added in a ratio of $2: 1(\mathrm{v} / \mathrm{v})$, agitated for $1 \mathrm{~min}$, and centrifuged at $15.303 \mathrm{x}$ g for $10 \mathrm{~min}$ at $25^{\circ} \mathrm{C}$. The organic phase containing the hexane was isolated and rotoevaporated for the determination of free pequi oil present. The amount of oil mass was measured in the pre-weighed boiling flask.

\subsection{Statistical analysis}

A completely randomized design was used in this work and the results represent the means of three replicates. The means were compared through Student's t-test. The statistical analysis was performed with Statistica 13.0 software.

\section{Results and Discussions}

\subsection{Microparticles without pequi oil}

In an acid medium, gelatin is positively charged (below the isoelectric point) and attracted to 
the negatively charged cashew gum to form coacervate droplets. Thus, the proportions of the encapsulating matrices were determined based on an electrical equivalence study performed through an electrical charge analysis (zeta potential) of each biopolymer in solution at $\mathrm{pH} 4.0,4.5$ and 5.0. The zeta potential values of the polysaccharides and protein in the $\mathrm{pH}$ range at room temperature are shown in Table 1.

The optimum condition for coacervate formation is reached at a $\mathrm{pH}$ where the associated biopolymers are electrically equivalent in terms of opposing charges (Comunian et al., 2016; de Kruif, Weinbreck \& de Vries, 2004; Schmitt \& Turgeon, 2011). In order to reach this electrical neutrality, the proportions found for the CG/GE treatments were $2: 1$ at $\mathrm{pH} 4.5$ and $1: 1$ at $\mathrm{pH} 5.0$; for the GA/GE treatment, they were $1: 4$ at $\mathrm{pH} 4.0$ and $1: 5$ at $\mathrm{pH} 4.5$. However, in an attempt performed with 1:5 ratio at $\mathrm{pH} 4.5$, the GA/GE suspension after refrigeration $\left(8^{\mathrm{O}} \mathrm{C} \pm 2\right)$ formed a very viscous gel due to the high gelatin concentration, making it impossible to form the coacervate droplets. For this reason, the ratio was reduced to $1: 3$ at $\mathrm{pH}$ 4.5. Thus, the formation of the polyelectrolyte complex depends on the degree of polymer ionization, and, therefore, on the $\mathrm{pH}$. In addition, the polymer stoichiometry, structural parameter (conformation and chain length), and other parameters such as ionic strength, temperature and nature of the reactants may also exert an influence on the complex formation and stability (Kim et al., 2016; Siow \& Ong, 2013). Thus, although the electrical equivalence of the complexes has been deduced for the polymers separately, the zeta potential corresponding to each complex formed was also analyzed, as shown in Table 2.

$\mathrm{G} / \mathrm{GE}$, at the ratio of $2: 1$ and $\mathrm{pH} 4.5$, showed a zeta potential value close to zero, demonstrating electrical equivalence between biopolymers that is conducive to coacervate formation. The combination of the two biopolymers in the proportion of $2.5: 1$ at $\mathrm{pH} 4.0$ was previously tested by Comunian et al. (2016) to encapsulate Echium oil, although a prospective study of the best proportion at a different $\mathrm{pH}$ range has not yet been reported. At $\mathrm{pH}$ 4.5, GE acquires a positive charge and forms coacervates with anionic polysaccharides, as does GA. As the GE used is type B (acidic) and its isoelectric point lies in the range of 4.7 to 5.3 , the $\mathrm{pH}$ selected to encapsulate pequi oil was in accordance with those reported in the literature (Azeredo, 2008).

The absorbance of the CG/GE and GA/GE suspensions before and after the refrigeration process $\left(8 \pm 2{ }^{\circ} \mathrm{C}\right)$ was monitored, so that the absorbance variation could be related to the coacervate precipitation. The results of the absorbance variation for the $\mathrm{CG} / \mathrm{GE}$ and $\mathrm{GA} / \mathrm{GE}$ treatments are shown in Figure 1.

A greater absorbance variation was found in the CG/GE complex at ratio $2: 1$ and $\mathrm{pH} 4.5$, indicating a higher level of coacervate precipitation when compared to 1:1 at $\mathrm{pH}$ 5.0. For the GA/GE treatment, the ratio of $1: 4$ at $\mathrm{pH} 4.0$ possibly presented a negative variation, indicating that, after refrigeration $\left(8 \pm 2{ }^{\circ} \mathrm{C}\right)$, the suspension became cloudier than before, probably because of the formation of a very dense gel. The negative absorbance variation value reflected the poor coacervate precipitation in this condition. However, for the ratio of $1: 3$ at $\mathrm{pH} 4.5$, it displayed a considerable variation in absorbance and, consequently, more significant coacervate precipitation.

The conditions determined for each CG/GE and GA/GE complex were also evaluated regarding yield at a $\mathrm{pH}$ range. Yield is important because it is related to the production cost of the encapsulation process. The result found was in agreement with spectrophotometric and zeta potential data, where the treatments for 2:1 CG/GE at $\mathrm{pH} 4.5$ and $1: 3 \mathrm{GA} / \mathrm{GE}$ at $\mathrm{pH} 4.5$ were found to be the most appropriate for coacervate formation (Figure 2).

\subsection{Microparticles with pequi oil}

Pequi oil microparticles were produced using five levels of oil $(0.5 \mathrm{~g}, 0.75 \mathrm{~g}, 1 \mathrm{~g}, 2 \mathrm{~g}$ and $2.5 \mathrm{~g})$ while adhering to the experimental settings of 2:1 CG/GE at pH 4.5 and 1:3 GA/GE at $\mathrm{pH} 4.5$. Microparticles formed and precipitated were subjected to yield and particle size analysis by laser diffraction.

The yield based on dry-weight of the microparticles formed is shown in Figure 3. Through this analysis it was possible to establish a rela-

IJFS | January 2020 | Volume 9 | pages SI97-SI109 
Table 1: Zeta potential values of cashew gum (CG), gum Arabic (GA) and gelatin (GE) in the pH range from 4.0 to 5 at room temperature.

\begin{tabular}{cccc}
\hline & $\mathrm{CG}(1 \% \mathrm{w} / \mathrm{v})$ & $\mathrm{GA}(1 \% \mathrm{w} / \mathrm{v})$ & $\mathrm{GE}(1 \% \mathrm{w} / \mathrm{v})$ \\
\hline $\mathrm{pH}$ & \multicolumn{3}{c}{ Zeta potential $(\mathrm{mV})$} \\
\hline 4.0 & 3.11 & -16.40 & 3.65 \\
4.5 & -2.09 & -21.07 & 4.24 \\
5.0 & -1.55 & -21.80 & 1.02 \\
\hline
\end{tabular}

Table 2: Zeta potential values of coacervate suspensions without pequi oil at different $\mathrm{pH}$ values after cooling $\left(8^{\circ} \mathrm{C}\right)$ overnight for precipitation of the particles. The measurements were conducted at room temperature.

\begin{tabular}{lll}
\hline Treatment & Ratio $(\mathrm{w} / \mathrm{w})$ and $\mathrm{pH}$ & Zeta potential $(\mathrm{mV})^{*}$ \\
\hline CG/GE & $2: 1 \mathrm{pH} 4.5$ & $-0.25 \pm 0.47^{a}$ \\
& $1: 1 \mathrm{pH} 5.0$ & $-2.96 \pm 0.70^{b}$ \\
GA/GE & $1: 4 \mathrm{pH} 4.0$ & $7.25 \pm 2.33^{c}$ \\
& $1: 3 \mathrm{pH} 4.5$ & $1.34 \pm 0.41^{d}$ \\
\hline
\end{tabular}

*All mean zeta potentials differed significantly $(\mathrm{p} \geq 0.05)$.

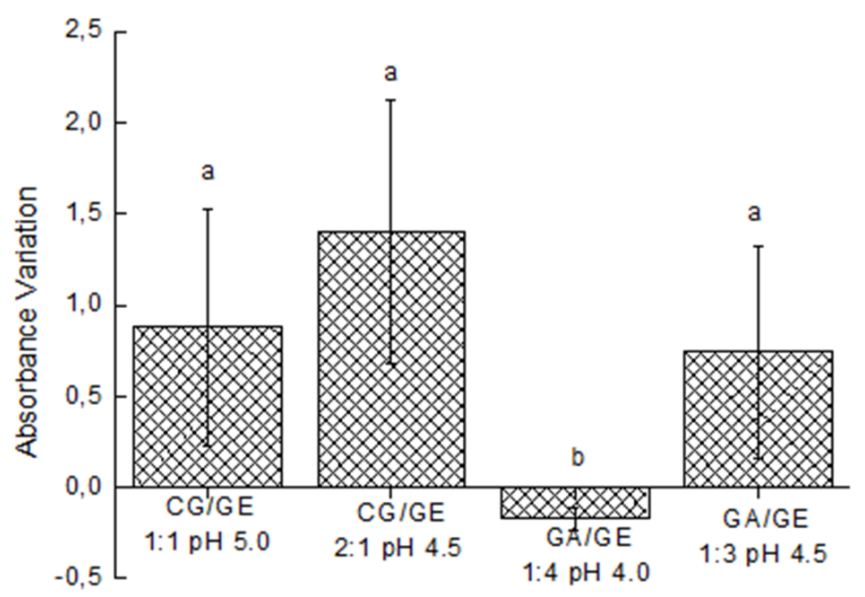

Figure 1: The variation of absorbance (at $200 \mathrm{~nm}$ ) before and after coacervate refrigeration $(8 \pm 2$ ${ }^{\circ} \mathrm{C}$ ) with the use of cashew gum/gelatin $(\mathrm{CG} / \mathrm{GE})$ at $1: 1 \mathrm{ratio} / \mathrm{pH} 5$ and $2: 1 \mathrm{ratio} / \mathrm{pH} 4.5$, and gum Arabic/gelatin (GA/GE) at 1:4 ratio/pH 4 and 1:3 ratio/pH 4.5. Bars: standard deviations $(\mathrm{n}=3)$ 
Pequi oil microencapsulation by coacervation $\mid$ SI103

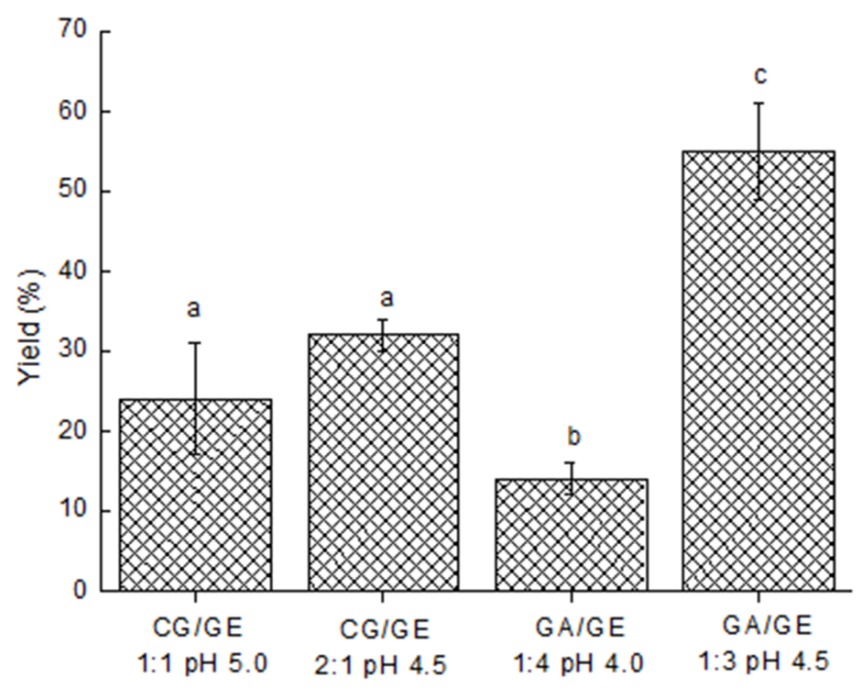

Figure 2: Coacervate yields of cashew gum/gelatin (CG/GE) at 1:1 ratio/pH 5.0 and 2:1 ratio/pH 4.5, and gum Arabic/gelatin (GA/GE) at 1:4 ratio/pH 4.0 and 1:3 ratio/pH 4.5 after drying in an oven at $105{ }^{\circ} \mathrm{C}$. Bars: standard deviations $(\mathrm{n}=3)$

tionship between the matrix components and the core and coacervate formation, thereby avoiding material waste and ensuring optimal conditions for encapsulation.

Higher yields of $\mathrm{CG} / \mathrm{GE}$ particles were found at the lower oil levels. According to de Conto, Grosso and Gonçalves (2013), the higher the wall material concentration and the lower the oil concentration, the higher the yield. However, GA/GE had a higher proportion of wall material in the coacervation process, and we obtained a higher yield when a larger quantity of oil was used. Therefore, in the ensuing work, the use of $1 \mathrm{~g}$ and $2.5 \mathrm{~g}$ of pequi oil was selected, respectively, for the treatments of $2: 1 \mathrm{CG} / \mathrm{GE}$ at $\mathrm{pH} 4.5$ and 1:3 GA/GE at $\mathrm{pH}$ 4.5. The $2: 1 \mathrm{GC} / \mathrm{GE}$ and $1: 3$ GA/GE particles had a moisture content of 4.7 $\pm 0.50 \%$ and $5.54 \pm 0.16 \%$, respectively. These were the largest quantities of oil among those tested with each treatment that had good yield values. Yield results show that GA/GE matrix was more promising than $\mathrm{CG} / \mathrm{GE}$ in pequi oil encapsulation. However, cashew gum is a reasonable alternative to gum Arabic especially for use in cashew-producing areas in the world.

The size distribution of the particles obtained by laser diffraction analysis displayed a unimodal distribution for the $\mathrm{CG} / \mathrm{GE}$ and $\mathrm{GA} / \mathrm{GE}$ treatments. The average particle size values are shown in Figure 4. The $\mathrm{D}_{4,3}$ particles were micrometric in size, with GA/GE (4311.85 \pm 1428.32 $\mathrm{nm}$ ) smaller than CG/GE particles (8216.72 \pm $1853.32 \mathrm{~nm})$. The Span value found was $0.45 \pm$ 0.04 and $0.23 \pm 0.03$ for $\mathrm{GA} / \mathrm{GE}$ and $\mathrm{CG} / \mathrm{GE}$ respectively, indicating a small dispersity of the particles. Optical microscopy analysis also confirmed the smaller size of GA/GE particles (Figure 5). It is known that the particle size distribution of emulsion droplets is affected by many factors relating to biopolymers and $\mathrm{pH}$, e.g., the addition rate of the acidifying agent for anionic polysaccharides and the rate of formation of gelatin coacervates (Jyothi et al., 2010). In this work the greater amount of gelatin employed in the GA/GE complex probably promoted a better emulsification of the solution and resulted in smaller particles. 

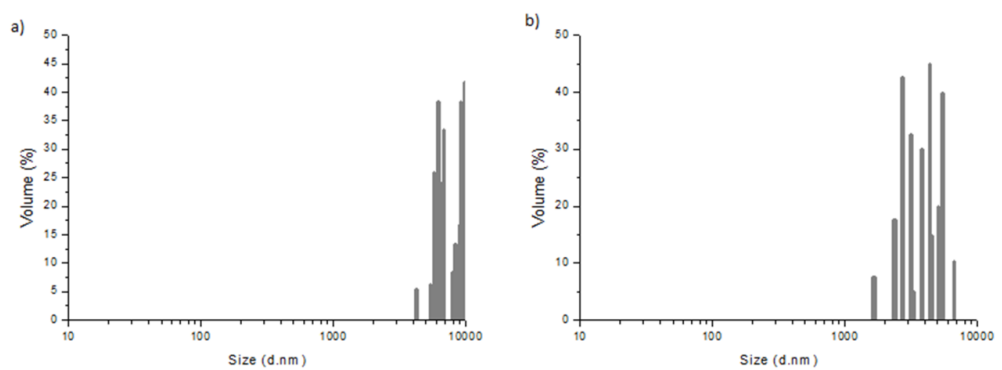

Figure 3: Microparticle yields with $0.5 \mathrm{~g}, 0.75 \mathrm{~g}, 1 \mathrm{~g}, 2 \mathrm{~g}$ and $2.5 \mathrm{~g}$ of pequi oil in cashew gum/gelatin matrices (CG/GE) at ratio 2:1/pH 4.5 and gum Arabic/gelatin (GA/GE) at ratio 1:3/pH 4.5 after drying in an oven at $105{ }^{\circ} \mathrm{C}$. Bars: standard deviations $(\mathrm{n}=3)$
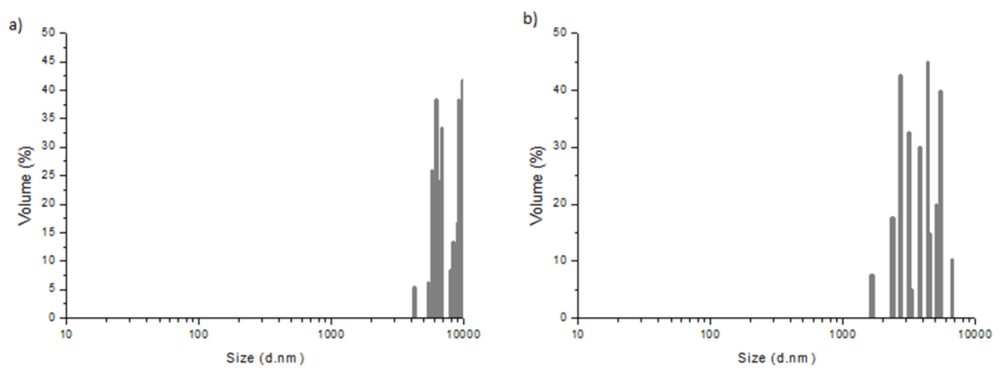

Figure 4: Size of microparticles of (a) cashew gum/gelatin (CG/GE) at ratio 2:1/pH 4.5 with $1 \mathrm{~g}$ of pequi oil, and (b) gum Arabic/gelatin (GA/GE) at ratio $1: 3 / \mathrm{pH} 4.5$ with $2.5 \mathrm{~g}$ of pequi oil. The measurements were conducted at room temperature.
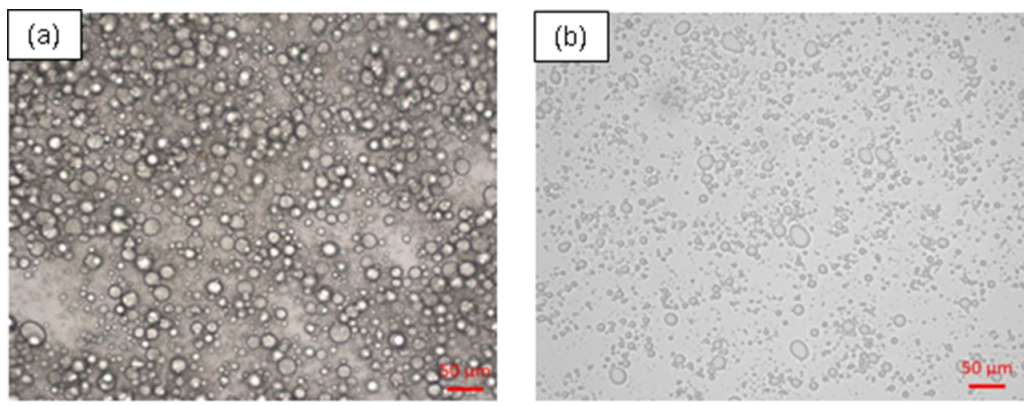

Figure 5: Images obtained by optical microscopy of (a) cashew gum/gelatin (CG/GE) microparticles with $1 \mathrm{~g}$ of pequi oil, and (b) gum Arabic/gelatin (GA/GE) with $2.5 \mathrm{~g}$ of pequi oil. The measurements were conducted at room temperature. 


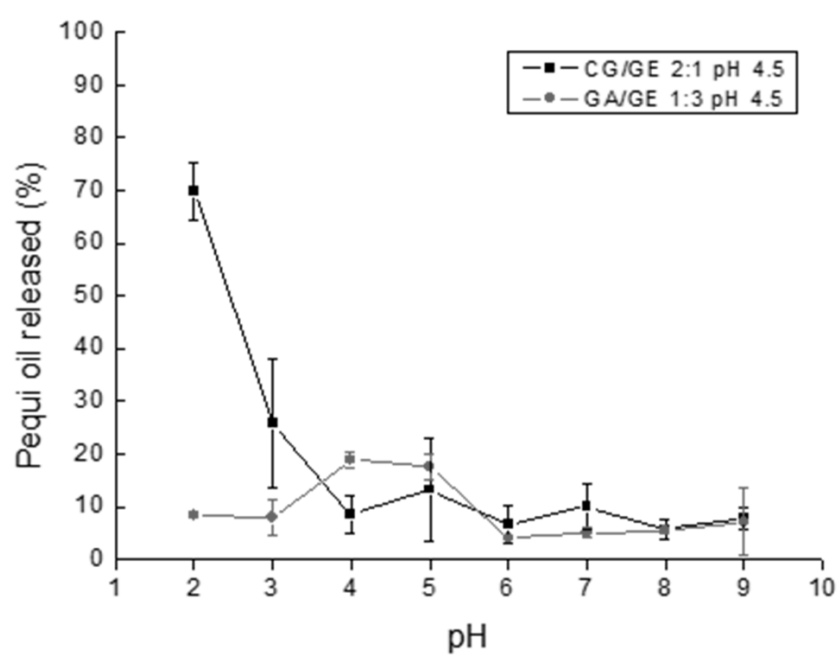

Figure 6: Pequi oil release from cashew gum/gelatin (CG/GE) microparticles at 2:1 ratio/pH 4.5 with $1 \mathrm{~g}$ of pequi oil, and gum Arabic/gelatin (GA/GE) at $1: 3 \mathrm{ratio} / \mathrm{pH} 4.5$ with $2.5 \mathrm{~g}$ of pequi oil, in the $\mathrm{pH}$ range of 2.0 to 9.0 at room temperature. Bars: standard deviations $(\mathrm{n}=3)$

\section{Encapsulation efficiency}

Encapsulation efficiency (EE) reflects the amount of oil trapped inside the particles. $\mathrm{GC} / \mathrm{GE}$ and $\mathrm{GA} / \mathrm{GE}$ showed $\mathrm{EE}$ of $72.53 \%$ $( \pm 4.80)$ of $82.77 \%( \pm 6.09)$, respectively. Oil retention within the particles is affected by the encapsulation method and the nature of the biopolymers, as well as the particle wall thickness. Thus, a larger amount of wall material may favour oil retention and consequently optimize the encapsulation efficiency (Tang \& Li, 2013). In this work, the experimental parameters for polysaccharide-protein complexation were experimentally determined that aimed at the best conditions for coacervate formation, and therefore showed different proportions that also resulted in statistically different EE (p $<5 \%$ ). Similar EE are found in literature using gum Arabic and gelatin for oil encapsulation, although there are different sources, suppliers and viscoelastic properties of gelatin. Liu, Low and T. Nickerson (2010) reported flaxseed oil EE of $84 \%$ using type-A gelatin from porcine skin and gum Arabic 1:1 at a constant total biopolymer concentration $(2 \% \mathrm{w} / \mathrm{v})$ and core-to-wall ratio (50:50). Gonçalves, Grosso, Rabelo, Hubinger and Prata (2018) worked with type-B gelatin from bovine skin and gum Arabic 1:1 for thyme essential oil encapsulation and found $\mathrm{EE}$ of $90 \%$. Marfil, Paulo, Alvim and Nicoletti (2018) foundan EE of $83.5 \%$ for palm oil encapsulation using a $2 \%$ concentration of wall material (gelatin type-B from bovine skin and gum Arabic) and 42.8: 57:2 ratio between core and wall material.

\section{Oil release}

The release of the core material is facilitated by certain conditions, such as $\mathrm{pH}$ alteration, mechanical stress, temperature, time and osmotic force, among others. This kind of study may be useful for future commercial applications in order to avoid unwanted release and thus contribute to preserving the integrity of the active compound. In this study we evaluated the oil release in the $\mathrm{pH}$ range from 2 to 9 .

The 2:1 CG/GE treatment presented a high oil release with acidic $\mathrm{pH}$, practically reaching a re-

IJFS | January 2020 | Volume 9 | pages SI97-SI109 
lease of $70 \%$ at $\mathrm{pH} 2.0$. This release decreased until $\mathrm{pH}$ reached 4.0, and then showed slight oscillations until $\mathrm{pH}$ reached 9.0. It can be affirmed that the $\mathrm{pH}$ range in which these microparticles released the most oil was between 2.0 and 3.0. This behaviour is visualized in Figure 6 . Since the complex coacervation process is strongly influenced by $\mathrm{pH}$ variations, it is likely that in more acidic $\mathrm{pH}$ ranges, in which there should be a large $\mathrm{CG} / \mathrm{GE}$ oil release, the electrostatic interactions that depend on the degree of biopolymer ionization have been undone, leading to a greater oil release. On the other hand, 1:3 GA/GE treatment exhibited low release in the $\mathrm{pH}$ range evaluated in this study $(<20 \%)$. According to Shaddel et al. (2018) the best potential food items for enrichment purposes using gum Arabic and gelatin wall material and black raspberry core seem to be the ones with the $\mathrm{pH}$ values between 3.0 and 5.0. Siow and Ong (2013) evaluated garlic oil release from gelatin and gum Arabic particles and found about $90 \%$ release during incubation at 37 ${ }^{o} \mathrm{C}$ in pepsin solution ( $\mathrm{pH} 2$ ) for $3 \mathrm{~h}$. The same authors demonstrated that the oil release from microparticles is slower in cross-linked particles.

\section{Conclusion}

Pequi oil was successfully incorporated during the formation of $\mathrm{CG} / \mathrm{GE}$ coacervates. Food applications for these microparticles involving a $\mathrm{pH}$ above 3 are recommended because of the greater oil release at acidic pH. It is clear that cashew gum has great potential as an encapsulation matrix, although it is possible to encapsulate a larger amount of pequi oil using GA/GE. Since cashew gum is a by-product of the cashew industry and currently has little commercial value, the possibility of using cashew gum for encapsulation should be a welcome development for the industry.

\section{Acknowledgements}

The authors thank CAPES for providing a fellowship for Marília Alves and Rousselot Company for supplying the gelatin for this project. Mention of trade names or commercial products in this publication is solely for the purpose of providing specific information and does not imply recommendation or endorsement by the U.S. Department of Agriculture. USDA is an equal opportunity provider and employer.

\section{References}

Aguilera, J. M. (2005). Why food microstructure? Journal of Food Engineering, 67(1), 3-11. IV Iberoamerican Congress of Food Engineering (CIBIA IV). doi:https://doi. org/10.1016/j.jfoodeng.2004.05.050

Alvim, I. D. \& Ferreira Grosso, C. R. (2010). Microparticles obtained by complex coacervation: Influence of the type of reticulation and the drying process on the release of the core material. Ciencia E Tecnologia De Alimentos, 30(4), 1069-1076. doi:10.1590/ S0101-20612010000400036

Andrade, K. C. S., Carvalho, C. W. P. d. \& Takeiti, C. Y. (2013). Goma de cajueiro (anacardium occidentale): Avaliação das modificações químicas e físicas por extrusão termoplástica. Polímeros, 23, 667671. doi:10.4322/polimeros.2013.004

Anvari, M. \& Chung, D. (2016). Dynamic rheological and structural characterization of fish gelatin-gum arabic coacervate gels crosslinked by tannic acid. Food Hydrocolloids, 60, 516-524. doi:10.1016/j.foodhyd.2016. 04.028

Azeredo, H. (2008). Encapsulação: Aplicação à tecnologia de alimentos. Alimentos e $\mathrm{Nu}$ trição, 16 .

Azevedo-Meleiro, C. H. \& Rodriguez-Amaya, D. B. (2004). Confirmation of the identity of the carotenoids of tropical fruits by hplcdad and hplc-ms. Journal of Food Composition and Analysis, 17(3-4), 385-396. doi:10.1016/j.jfca.2004.02.004

Batista, J. S., Silva, A. E., Rodrigues, C. M. F., Costa, K. M. F. M., Oliveira, A. F., Paiva, E. S., .. Olinda, R. G. (2010). Avaliação da atividade cicatrizante do óleo de pequi (caryocar coriaceum wittm) em feridas cutâneas produzidas experimentalmente em ratos. Arquivos do Instituto Biológico, 77(3), 441-47. 
Black, K. A., Priftis, D., Perry, S. L., Yip, J., Byun, W. Y. \& Tirrell, M. (2014). Protein encapsulation via polypeptide complex coacervation. ACS Macro Letters, 3(10), 1088-1091. doi:10.1021/mz500529v

Checci, H. M. (2003). Fundamentos teóricos e práticos em análises de alimentos. Campinas: Editora da Unicamp.

Comunian, T. A., Gomez-Estaca, J., FerroFurtado, R., Andrade Conceicao, G. J., Freitas Moraes, I. C., de Castro, I. A. \& Favaro-Trindade, C. S. (2016). Effect of different polysaccharides and crosslinkers on echium oil microcapsules. Carbohydrate Polymers, 150, 319-329. doi:10.1016/j . carpol.2016.05.044

da Silva, L. C., do Nascimento, M. A., Mendes, L. G., Furtado, R. F., Correia da Costa, J. M. \& Herzog Cardoso, A. L. (2018). Optimization of cashew gum and chitosan for microencapsulation of pequi oil by complex coacervation. Journal of Food Processing and Preservation, 42(3). doi:10.1111/jfpp. 13538

de Conto, L. C., Grosso, C. R. F. \& Gonçalves, L. A. G. (2013). Chemometry as applied to the production of omega-3 microcapsules by complex coacervation with soy protein isolate and gum arabic. LWT-Food Science and Technology, 53(1), 218-224. doi:https: //doi.org/10.1016/j.lwt.2013.02.017

de Kruif, C. G., Weinbreck, F. \& de Vries, R. (2004). Complex coacervation of proteins and anionic polysaccharides. Current Opinion in Colloid $\mathcal{E}$ Interface Science, 9(5), 340-349. doi:10.1016/j.cocis.2004.09.006

de Oliveira, E. F., Paula, H. C. B. \& de Paula, R. C. M. (2014). Alginate/cashew gum nanoparticles for essential oil encapsulation. Colloids and Surfaces B-biointerfaces, 113, 146-151. doi:10.1016/j.colsurfb.2013. 08.038

de Paula-Ju, W., H. Rocha, F., Donatti, L., Fadel-Picheth, C. \& Weffort-Santos, A. (2006). Leishmanicidal, antibacterial, and antioxidant activities of caryocar brasiliense cambess leaves hydroethanolic extract. Revista Brasileira De Farmacognosia-brazilian Journal of Pharmacognosy-REV BRAS FAR-
MACOGN, 16. doi:10 . 1590 / S0102 695X2006000500007

de Souza, V. B., Thomazini, M., Echalar Barrientos, M. A., Nalin, C. M., Ferro-Furtado, R., Genovese, M. I. \& Favaro-Trindade, C. S. (2018). Functional properties and encapsulation of a proanthocyanidin-rich cinnamon extract (cinnamomum zeylanicum) by complex coacervation using gelatin and different polysaccharides. Food Hydrocolloids, 77, 297-306. doi:10.1016/j.foodhyd.2017. 09.040

Gomez-Estaca, J., Comunian, T. A., Montero, P., Ferro-Furtado, R. \& Favaro-Trindade, C. S. (2016). Encapsulation of an astaxanthincontaining lipid extract from shrimp waste by complex coacervation using a novel gelatin-cashew gum complex. Food Hydrocolloids, 61, 155-162. doi:10. 1016 / j . foodhyd.2016.05.005

Gonçalves, N. D., Grosso, C. R., Rabelo, R. S., Hubinger, M. D. \& Prata, A. S. (2018). Comparison of microparticles produced with combinations of gelatin, chitosan and gum arabic. Carbohydrate Polymers, 196, 427-432. doi:https:// doi.org/10.1016/j. carbpol.2018.05.027

Gouin, S. (2004). Microencapsulation: Industrial appraisal of existing technologies and trends. Trends in Food Science \&3 Technology, 15(7-8), 330-347. doi:10.1016/j.tifs. 2003.10.005

Habibi, A., Keramat, J., Hojjatoleslamy, M. \& Tamjidi, F. (2017). Preparation of fish oil microcapsules by complex coacervation of gelatin-gum arabic and their utilization for fortification of pomegranate juice. Journal of Food Process Engineering, 40(2). doi:10. 1111/jfpe. 12385

Higuita, D. M. C. (2013). Microencapsulação de oleoresina de cúrcuma (curcuma longa l.) em misturas de goma arábica, maltodextrina e amido modificado (Master's thesis, Universidade Estadual Paulista (UNESP)).

Hosseini, S. M., Hosseini, H., Mohammadifar, M. A., Mortazavian, A. M., Mohammadi, A., Khosravi-Darani, K., ... Khaksar, R. (2013). Incorporation of essential oil in alginate microparticles by multiple emulsion/ionic gelation process. International 
Journal of Biological Macromolecules, 62, 582-588. doi:10.1016/j.ijbiomac.2013.09. 054

Huang, G.-Q., Sun, Y.-T., Xiao, J.-X. \& Yang, J. (2012). Complex coacervation of soybean protein isolate and chitosan. Food Chemistry, 135(2), 534-539. doi:10.1016/ j . foodchem.2012.04.140

Jafari, S.-M., Mahdavi-Khazaei, K. \& HemmatiKakhki, A. (2016). Microencapsulation of saffron petal anthocyanins with cress seed gum compared with arabic gum through freeze drying. Carbohydrate Polymers, 140, 20-25. doi:10.1016/j.carbpol.2015.11.079

Jyothi, N. V. N., Prasanna, P. M., Sakarkar, S. N., Prabha, K. S., Ramaiah, P. S. \& Srawan, G. Y. (2010). Microencapsulation techniques, factors influencing encapsulation efficiency. Journal of Microencapsulation, 27(3), 187-197. doi:10.3109/ 02652040903131301

Khoshakhlagh, K., Koocheki, A., Mohebbi, M. \& Allafchian, A. (2017). Development and characterization of electrosprayed alyssum homolocarpum seed gum nanoparticles for encapsulation of d-limonene. Journal of Colloid and Interface Science, 490, 562575. doi:10.1016/j.jcis.2016.11.067

Kim, S., Huang, J., Lee, Y., Dutta, S., Yoo, H. Y., Jung, Y. M., ... Hwang, D. S. (2016). Complexation and coacervation of like-charged polyelectrolytes inspired by mussels. Proceedings of the National Academy of Sciences of the United States of America, 113(7), E847-E853. doi:10.1073/ pnas. 1521521113

Liu, S., Low, N. \& T. Nickerson, M. (2010). Entrapment of flaxseed oil within gelatin-gum arabic capsules. Journal of the American Oil Chemists' Society, 87, 809-815. doi:10. 1007/s11746-010-1560-7

Lopes, P. S., Pinto, C. A. S. d. O., Baby, A. R., Velasco, M. V. R., Taqueda, M. E. \& Kaneko, T. M. (2008). Evaluation of in vitro percutaneous enhancement effect of papain and pequi oil on diclofenac sodium permeation through human skin. Revista Brasileira De Ciencias Farmaceuticas, 44(2), 225-231.
Lv, Y., Yang, F., Li, X., Zhang, X. \& Abbas, S. (2014). Formation of heat-resistant nanocapsules of jasmine essential oil via gelatin/gum arabic based complex coacervation. Food Hydrocolloids, 35, 305-314. doi:10.1016/j.foodhyd.2013.06.003

Marfil, P. H. M., Paulo, B. B., Alvim, I. D. \& Nicoletti, V. R. (2018). Production and characterization of palm oil microcapsules obtained by complex coacervation in gelatin/gum arabic. Journal of Food Process Engineering, 41(4). doi:10.1111/jfpe. 12673

Pianovski, A. R., Vilela, A. F. G., da Silva, A. A. S., Lima, C. G., da Silva, K. K., Carvalho, V. F. M., .. Ferrari, M. (2008). Uso do óleo de pequi (caryocar brasiliense) em emulsões cosméticas: Desenvolvimento e avaliação da estabilidade física. Revista Brasileira de Ciências Farmacêuticas, 44(2), 249-259.

Prata, A. S. \& Grosso, C. R. F. (2015). Production of microparticles with gelatin and chitosan. Carbohydrate Polymers, 116, 292-299. doi:10.1016/j.carbpol.2014.03.056

Quirino, G. d. S., Leite, G. d. O., Rebelo, L. M., Tome, A. d. R., Martins da Costa, J. G., Cardoso, A. H. \& Campos, A. R. (2009). Healing potential of pequi (caryocar coriaceum wittm.) fruit pulp oil. Phytochemistry Letters, 2(4), 179-183. doi:10.1016/j. phytol.2009.06.002

Re, M. I. (2006). Formulating drug delivery systems by spray drying. Drying Technology, 24(4), 433-446. doi:10 . 1080 / 07373930600611877

Revuelta, M. V., Chacon Villalba, M. E., Navarro, A. S., Guida, J. A. \& Castro, G. R. (2016). Development of crystal violet encapsulation in pectin-arabic gum gel microspheres. Reactive 6 Functional Polymers, 106, 8-16. doi:10.1016/j.reactfunctpolym. 2016.07.002

Rodrigues, R. A. F. \& Grosso, C. R. F. (2008). Cashew gum microencapsulation protects the aroma of coffee extracts. Journal of Microencapsulation, 25(1), 13-20. doi:10. 1080/02652040701725486

Rodrigues, R. A. F. (2004). Preparo, caracterização e avaliação funcional de mi- 
Pequi oil microencapsulation by coacervation $\mid$ SI109

crocápsulas obtidas por spray-drying, contendo extrato de café crioconcentrado (Doctoral dissertation, University State of Campinas, BR).

Schmitt, C. \& Turgeon, S. L. (2011). Protein/polysaccharide complexes and coacervates in food systems. Advances in Colloid and Interface Science, 167(1-2, SI), 63-70. doi:10.1016/j.cis.2010.10.001

Shaddel, R., Hesari, J., Azadmard-Damirchi, S., Hamishehkar, H., Fathi-Achachlouei, B. \& Huang, Q. (2018). Use of gelatin and gum arabic for encapsulation of black raspberry anthocyanins by complex coacervation. International Journal of Biological Macromolecules, 107(B), 1800-1810. doi:10.1016/j.ijbiomac.2017.10.044

Siow, L.-F. \& Ong, C.-S. (2013). Effect of ph on garlic oil encapsulation by complex coacervation. Journal of Food Processing \& Technology, 4.

Tang, C.-H. \& Li, X.-R. (2013). Microencapsulation properties of soy protein isolate and storage stability of the correspondingly spray-dried emulsions. Food Research International, 52(1), 419-428. doi:10.1016/ j.foodres.2012.09.010

Torquato, D. S., Ferreira, M. L., Sa, G. C., Brito, E. S., Pinto, G. A. S. \& Azevedo, E. H. F. (2004). Evaluation of antimicrobial activity of cashew tree gum. World Journal of Microbiology \& Biotechnology, 20(5), 505507. doi:10 . 1023 / B : WIBI . 0000040407. 90110.c5 